\title{
Incidence of IFRS for SMES in the financial sustainability on the Alpaquero textile sector of Perú, 2018
}

\author{
Constante Eduardo Jara Ortega ${ }^{1 *}$, Daniel Eduardo Jara Rodríguez ${ }^{2}$, Flor Vanessa Huamán Callo ${ }^{3}$ \\ 1, 2,3 Faculty of Accounting and Financial Sciences, Universidad Nacional de San Agustín, Arequipa, Perú
}

\author{
Keywords \\ IFRS \\ SMEs \\ Financial sustainability \\ Alpaquero \\ Textile sector
}

Received: 3 October 2019

Accepted: 6 November 2019

Published: 23 December 2019

\begin{abstract}
This research aims to demonstrate that with a correct order in the accounting management, internal control, and application of International Financial Reporting Standards (IFRS) for SMEs since an SME starts, it can consolidate its stability over time through greater financial sustainability. To that end, the company Millman y Qaytu was analyzed, an SME dedicated to the textile sector based in alpaca fiber. The accounting information was used from the creation of the company until the last available (2015 to 2017), proposing an applied investigation, correlational level, with non-experimental design and applying an adaptation to the specific case of the methodology proposed by (Bowman, 2011) ), which serves to measure the financial sustainability of an entity. As a result of the investigation, it was obtained that IFRS for SMEs positively impacts the sustainability of SMEs in the alpaquero textile sector. It is recommended that these international accounting standards be implemented by SMEs of the alpaquero textile sector to improve their financial sustainability.
\end{abstract}

\section{INTRODUCTION}

In a context of globalization, the textile industry in various countries has been affected by the incursion of new competitors in their markets, which, taking advantage of their best technology, cheap labor and manufacturing of largescale products, displace the local production and take away of the market the national companies. Thus, Asia has now become the largest productive focus and largest supplier of textile and clothing products for the whole world, given its large internal consumption, low manufacturing costs, cheap raw material, availability of a wide infrastructure and efficient transportation and export logistics.

Peru is no stranger to this reality and sees how national textile production, despite having a higher quality and generating jobs for more peruvians, is displaced by products from other countries, which, despite their low quality, become attractive for a consumer looking for the lowest price.

According to the Summary Report of the Economic Activity of the city of Arequipa-March 2017, issued by the Department of Economic Studies of the Central Reserve Bank of Peru (BCRP), there has been a contraction of non-primary manufacturing, determined in part by the lower production of textile fiber and clothing yarns, whose real percentage variations with respect to the same period of the previous year amount to $-24.8 \%$ and $-1.0 \%$ respectively.

In that sense, we can appreciate that in recent periods the textile industry of Arequipa has been decreasing its manufacturing production rates, in such a way that the level of investment and consequent assumed risk that companies in general are willing to take have been reduced. This sector is generating a decrease in jobs, negative impact on regional competitiveness as a focus of textile production and less development of this important industry.

Other problems that have been identified in the alpaquero textile sector are mentioned below:

a. Alpaca fiber producers normally live in deep places in Arequipa, the main one being the district of Callalli and other nearby Chivay. The living conditions of the alpaqueros are precarious and do not receive high compensation for their work (breeding, feeding, care and shearing of the alpacas), because of their economic condition, they are obliged to accept low prices for their product, it due to the

\footnotetext{
* corresponding author: Constante Eduardo Jara Ortega

†email: cjarao@unsa.edu.pe
} 
existence of commercialization modalities such as "rescue", which consists in the fact that a person called "rescuer", takes shopping bags, clothes, medicines and money to the remote places where alpaca fiber producers live, negotiating with them the delivery of these products in exchange for their fiber, with very little benefit for the producer.

b. The alpaca fiber market is very informal and disorganized, the result of which is that it is very difficult for alpaca fiber producers to negotiate prices, since they are not organized and have no bargaining power and are not formalized, then, they can not opt for financing and other benefits that allow them to improve their production process and obtain a better product.

c. Producers of alpaca fiber are reluctant to provide proof of payment, since many of them have a negative concept of the tax administration and do not want to be involved in problems with the treasury, therefore, they often condition the sale of their product to the delivery of liquidations of purchase of relatives or other similar modalities, which generates a potential tax risk for companies that acquire raw material in this way, since these are simulated acts.

d. Although there are associations of alpaca fiber collectors, due to the lack of coordination of the producers, an adequate collection market is not yet established, due to the lack of compliance with international technical standards for fiber quality, this product of the informal sector, which prevents access to resources and financing to acquire specialized machinery and advice to achieve optimum quality level.

e. The vast majority of the alpaquero textile industry is comprised of large companies, such as Michel \& Cía, Incalpaca and Art Atlas, who even set a standard price for alpaca fiber, as they are the largest buyers in the market.

f. A major limitation for the growth of the internal marketing market for alpaca fiber derivatives is that in other countries with less production costs (cheap labor, cheap materials, less taxes, etc.), textile products enter a very low price, which creates unsustainable competition for the domestic market, since unlike other latitudes and industries, in the alpaquero textile sector, no anti-dumping measures are currently taken against this phenomenon.

Faced with this problem, the accounting and financial perspective becomes vitally important because the information that is produced and provided to management, stakeholders and other users to make certain decisions, is essential to indicate the direction that a company must follow and also allow identify whether it is convenient to increase investment in production or expansion of plants.

Long ago, accounting science developed based on gen- erally accepted accounting principles, however, all this changed with the worldwide issuance of IFRS, thus acquiring accounting, a new global language. It is understood as such standards to International Accounting Standards (IAS), IFRS, Standard Interpretations Committee (SIC), International Financial Reporting Interpretations Committee (IFRIC) that were developed for application in large publicly traded companies, leaving out companies with lower economic margins. Thus, the IFRS for SME's (IFRS for SMEs) were published in July 2009 by the International Accounting Standards Board, in order to cover the need to standardize the new global language and accounting knowledge, not only for large companies, but also for small ones such as SMEs, so that this kind business can obtain more beneficial economic conditions in the face of a market that is constantly subject to changes and daily competitiveness. However, in Peru, the application of IFRS for SMEs is practically non-existent, due to the fact that, for companies in this economic sector, which are beginning to operate and therefore have very limited resources, it would generate greater cost of having to hire duly trained accounting professionals to use this accounting standard.

This research aims to demonstrate that while it is true to keep an accounting based on IFRS for SMEs, it is more expensive for a company, this entails a positive effect, which is to improve the financial sustainability of the entity over time, and by therefore, guarantee its continuity as a result of a better order and internal control, because in Peru, more than $50 \%$ of MYPES close before three years (Ruiz, 2018).

\section{LITERATURE REVIEW}

The application of accounting standards and their forms of interaction with various areas of the company that adopts them is configured as one of the most relevant objects of study for accounting sciences, since through these investigations address the importance of accounting within an organization. As an example of this, we can mention the work of Jaruga, Fijalkowska, and Jaruga-Baranowska (2007), who study the impact of IFRS on accounting regulation and practical application within the Polish context, focusing on the general effect produced in the financial statements with the application of these standards, for which they have resorted to the study of the financial information of companies listed on the Warsaw Stock Exchange. In the same line of ideas, other research related to this topic can be mentioned, such as that carried out by Ponce, Hlaciuc, Mateș, and Măciucă (2016), who focused on analyzing whether the disclosure of information is adequate within Romanian companies listed on the Stock Exchange, this under an IFRS appli- 
cation scheme; and that carried out by (Sarea \& Al Dalal, 2015), which from a general approach, study compliance with IFRS 7 in the companies listed on the Stock Exchange of the Kingdom of Bahrain, an Asian country that has a stock exchange that does not collects any type of taxes and therefore has a different treatment than the common stock exchanges in the world.

At national and global level, the study of the impact of IFRS, in general and for some specific items has been addressed in breadth.

At the local level of Peru, Ramirez and Marlene (2014), in his thesis entitled "Impact of IFRS on the development of large family businesses in Peru", concludes that the impact of the application of the IFRS on family businesses in Peru is positive, this in terms of the transparency of capital markets immersed in the regulations, in making business decisions that family businesses will make based on real, reliable financial information in accordance with the reality of the environment and in terms of the interest of investors who have towards the professionalism of innovative ideas of services and products that these family businesses own. In Colombia, (Romero \& Luna, 2015), in the work whose title is "Analysis of the Changes caused by the implementation of IFRS for SMEs in the financial structure of the customs agency Ascointer S.A. Level 1", carried out for the University of Cartagena, they conclude that the application of IFRS for SMEs encourages the development of a strategic administrative vision that contributes to the growth of the entity, in addition to having financial statements prepared under these standards open the door to international markets, unifies the accounting language and promotes new commercial relations.

A clear antecedent in the measurement of the financial sustainability of entities is that proposed by (Alatrash, 2018; Barquet, 2019; Endang \& Risal, 2017; Cyril \& Howard, 1991), which used only ratios to predict when a nonprofit entity was vulnerable in the significant financial aspects that compromised its integrity and continuity as an organization. These ratios were the total capital divided by total income, net income divided by gross income, administrative expenses divided by total expenses and Herfindahl index of the concentration of income in the entity.

Perfecting the above, one of the main models to assess financial sustainability is the model proposed by Bowman (2011), which proposes a series of adjusted financial indicators to measure sustainability. Bowman's model quantifies the concept of financial capacity. In addition, financial capacity is sized according to time.

\section{RESEARCH METHODOLOGY General Objective}

Determine the impact of IFRS for SMEs in the financial sustainability of SME in the alpaquero textile sector of Arequipa-Perú.

\section{Specific Objectives}

a) Describe financial sustainability and its components.

b) Determine the indicators of financial sustainability in SMEs in the alpaquero textile sector of Arequipa-Peru with information based on Search Results Web results Generally Accepted Accounting Principles (GAAP).

c) Determine the indicators of financial sustainability in SMEs in the alpaquero textile sector of the Arequipa Region with information based on IFRS for SMEs.

d) Compare the variation of the financial sustainability indicators based on GAAP and IFRS for SMEs in the alpaquero textile sector of the Arequipa Region through the Bowman method.

\section{Research Scope}

According to Hernandez, Fernandez-Collado, and BaptistaLucio (2014), this research has a correlational scope, since it is intended to establish or demonstrate a relationship between the variables under study, which in this case as an independent variable is the IFRS for SMEs and as a dependent variable financial sustainability.

\section{Design of the Investigation}

A non-experimental design has been proposed in the present investigation (Hernandez et al., 2014), since all the accounting information will be obtained based on already existing documentation of the Millma and Qaytu company, without manipulating any of the variables or subjecting them to a sensitization process.

\section{Population and Sample}

The population for this research is made up of SMEs dedicated to the alpaquero textile sector in the Arequipa region. The study unit will be: Millma \& Qaytu Statement of Accounting Concept (SAC), this sample was chosen in a nonprobabilistic way (Hernandez et al., 2014) by the convenience method. It is necessary to point out that one of the limitations of this research is that SMEs in the alpaquero textile sector are reluctant to provide their accounting information for research purposes, even offering them to keep their accounting for a period of one year free of charge, by accounting professionals highly trained. 


\section{Techniques to Use}

The main technique for the development of this research work is the documentary analysis, since a deep revision of the IFRS for SMEs and its corresponding application to the accounting information of the company Millma and Qaytu was required. Likewise, the method proposed by Bowman (2011) was used to measure the financial sustainability of the company under study.

\section{Procedures}

The accounting and financial information of the company Millma \& Qaytu SAC, from its creation, in 2015, until 2017, was adjusted to the parameters set by the IFRS for SMEs, adopting it as a reference framework for the registration and disclosure of information. After that, the methodology proposed by Bowman (2011) was applied, based on indicators to see sustainability before and after the adoption of IFRS for SMEs and determine when the entity is more sustainable.

\section{RESULTS AND DISCUSSION}

Diagnosis of Internal Control Failures in SME Companies in the Alpaquero Textile Sector

"Over the years, internal control has been defined from different perspectives, but that consistently follows the same objectives of achieving business goals, promoting operational efficiency and the reliability in the financial information of the economic units" (Santa Cruz, 2014). One of the advantages of applying IFRS for SMEs, is that some degree of internal control must necessarily be implemented in the accounting and financial information of the company, which results in a more efficient operational management, product of following validated and regulated accounting standards.

According to Hermanson, Smith, and Stephens (2012), Kakanda, Salim, and Chandren (2018), Nordin and Hamid (2013), Woods (2012), in any organization, risk plays a huge role in the success or failure of any business endeavor. That is why, within an activity as complicated as textile, and even more so in an exporting industry, the application of at least basic internal control is necessary to mitigate business inherent risks.

Thus, as a result of this investigation, the following internal control failures that are common in small and mediumsized companies in the textile sector have been identified:

a) Lack of adequate compliance with tax obligations, due to a low investment in adequate tax advice.

b) Since the alpaquero textile sector is very informal and the suppliers do not fulfill their tax obligations with the state, this prevents the company from fulfilling theirs.

c) An exhaustive control is not carried out in petty cash, which prevents having clear the true cash flows of the company.

d) Since the owners are usually also the managers, they do not differentiate the assets of the company from theirs, which generates withdrawals of money without control and purchase of assets and services for personal use, which can potentially generate various penalties before the tax administration.

e) People are hired informally, which can generate contingencies with the labor inspection entity.

f) The contributions of the partners, as well as their entry into the company's shareholders, are not formalized before public records.

g) There is no adequate cost of the products, so it is not known what the real profit is from the sale and export of products.

\section{Incidence of IFRS for SMEs in the Financial Sustainabil- ity}

The accounting and financial information of the company Millma and Qaytu, from its creation in 2015, until 2017, has been recorded and disclosed based on the accounting principles generally accepted in Peru, however, for the purpose of carrying out this investigation, this information has had to be adapted to the standards established by the IFRS for SMEs applicable to the economic reality of this company, being applicable to all sections of the standard, with the exception of the following sections: 9, 11, $12,14,15,16,18,19$, $24,26,28,31,33$ and 34 . As a result of the adoption of IFRS for SMEs, the corresponding accounting adjustments were made as indicated in this standard.

It is necessary to clarify that the information corresponding to 2018 is not yet worked, because due to the activity of the company and review procedures of the country's tax administration, there is no definitive balance for this year, given the high probability of making adjustments.

With the information available before and after the adoption of IFRS for SMEs for the years 2015, 2016 and 2017, we proceeded to calculate the indicators to measure financial sustainability according to the Bowman method for each case. The results are shown below: 
TABLE 1. Bowman Sustainability Indicators

\begin{tabular}{llll}
\hline \hline Indicator & $\mathbf{2 0 1 5}$ & $\mathbf{2 0 1 6}$ & $\mathbf{2 0 1 7}$ \\
\hline Equity (NA) GAAP & 0.09 & 0.12 & 0.50 \\
Equity (NA) IFRS & 0.11 & 0.26 & 0.60 \\
Return on Assets (ROA) GAAP & 0.11 & 0.08 & -0.15 \\
ROA IFRS & 0.15 & 0.31 & -0.10 \\
Months of Expenses (ME) GAAP & 1.30 & 0.63 & 12.00 \\
ME IFRS & 1.64 & 2.23 & 30.37 \\
Operating Margin (OM) GAAP & 0.10 & 0.02 & 0.59 \\
OM IFRS & 0.13 & 0.14 & 0.82 \\
Status Quo Operating Margin (SQ-OM) & 5.00 & 3.32 & 0.58 \\
GAAP & & & \\
SQ-OM IFRS & 5.23 & 3.86 & 0.81 \\
\hline \hline
\end{tabular}

For each indicator, the entity is compared to each other by three parameters:

- Number of times or years when the organization met the requirement for an indicator to be an organization with financial capacity and sustainability.

- Range of variation of the indicator.

- Average of the indicator in the three years included in the study.

The standard deviation and the coefficient of variation were not used as the comparison parameter for the following reasons: (i) The standard deviation measures the deviation of the data in its distribution with respect to the arithmetic mean, while what it is interesting to measure is the deviation of the data from the recommended value according to the Bowman model, (ii) the Coefficient of Variation (CV) was not used, because most of the data are percentages and the values of many data approach zero. In these cases, the value of the $\mathrm{CV}$ is very large, but it does not necessarily imply data dispersion.

The entity is rated for each parameter of the indicator, with 1 being the best rating and 2 the worst. Then, it receives a position for each indicator based on the average of the three qualifications. The entity's positions for each indicator are compared, then the entity receives the position separately for long-term and short-term financial sustainability. It is an average of the positions for each indicator.

The entity receives a final position as an average of the long and short term positions Comparing the results, the entity obtained the following positions in financial capacity and sustainability:

TABLE 2. Average of the Five Indicators of Financial Sustainability for the Entity Average of indicators (2015-2017)

\begin{tabular}{llllll}
\hline \hline Description/Indicator & NA & ROA & ME & OM & SQ-OM \\
\hline Equity (NA) GAAP & 0.24 & $1.65 \%$ & 4.64 & $24.36 \%$ & $2.97 \%$ \\
Equity (NA) IFRS & 0.33 & $12.48 \%$ & 11.41 & $37.10 \%$ & $3.30 \%$ \\
\hline \hline
\end{tabular}

TABLE 3. Range of the Five Indicators of Financial Sustainability for the Entity Average of indicators (2015-2017)

\begin{tabular}{llllll}
\hline \hline Description/Indicator & NA & ROA & ME & OM & SQ-OM \\
\hline Equity (NA) GAAP & 0.41 & $26.66 \%$ & 11.37 & $56.83 \%$ & $4.41 \%$ \\
Equity (NA) IFRS & 0.49 & $41.82 \%$ & 28.73 & $68.85 \%$ & $4.42 \%$ \\
\hline \hline
\end{tabular}

TABLE 4. Positioning of the Entity in Capacity and Financial Sustainability Financial Position

\begin{tabular}{llllllllll}
\hline \hline \multirow{2}{*}{$\begin{array}{l}\text { Term } \\
\text { Indicator Description }\end{array}$} & Nong & \multicolumn{9}{c}{ Short } & Average Position & Position \\
\cline { 2 - 9 } & ROA & Position & ME & OM & SQ-OM & Position & & \\
\hline Equity (NA) GAAP & 1 & 1 & 1 & 1 & 1 & 2 & 2 & 1.5 & 2 \\
Equity (NA) IFRS & 1 & 1 & 1 & 1 & 1 & 1 & 1 & 1 & 1 \\
\hline \hline
\end{tabular}

\section{CONCLUSION}

- Initial financial information based on GAAP showed favorable indicators in Equity (NA), very negative indexes in the SQ-OM and asset turnover ROA, finally the ME and the OM showed a decline in the second year, recovering in the third despite low sales.
- The main indicators impacted by the adoption of IFRS for SMEs are ROA, months of expenses (ME) and operating margin $(\mathrm{OM})$, however, the greater variation in the range of data generated volatility in these indicators, which ultimately led to a lower perspective of financial sustainability.

- When comparing the financial sustainability indicators, 
based on both GAAP and IFRS for SMEs, a significant difference was obtained in several indicators, especially in 2016 due to the increase in equity variation, however, the financial sustainability indicators on average have reflected relevant differences only in the short-term financial position of the SQ-OM, due in part to the simplicity of operations.

\section{IMPLICATIONS}

It is verified that the company Millma \& Qaytu after the adoption of IFRS for SMEs is more sustainable than before such adoption (it has a better financial position with the value of 1 ), so it is recommended that these international accounting standards be implemented by SMEs of the alpaquero textile sector, to improve their financial sustainability.

\section{ACKNOWLEDGEMENT}

We thank the Universidad Nacional de San Agustín de Arequipa, which through the contract No. IBA-0011-2017-UNSA, has financed this article, within the framework of the research project called "Incidence of IFRS in the Economic and Financial growth and sustainability of SMEs of the Alpaquero Textile Sector of Arequipa Region, 2016".

\section{REFERENCES}

Alatrash, A. (2018). Impact of using total quality management on the financial performance of companies listed on the Palestine exchange. International Journal of Business and Economic Affairs, 3(6), 244-252. doi:https://doi.org/10 .24088/IJBEA-2018-36001

Barquet, E. A. G. (2019). Analysis of the consumer behavior of the members of the savings and credit cooperatives for the integration of electronic financial services in the city of Guayaquil . International Journal of Business and Administrative Studies, 5(5), 303-311. doi:https://dx.doi.org/10.20469/ijbas.5.10005-5

Bowman, W. (2011). Financial capacity and sustainability of ordinary nonprofits. Nonprofit Management and Leadership, 22(1), 37-51. doi:https://doi.org/10.1002/nml.20039

Cyril, F. C., \& Howard, P. T. (1991). Financial vulnerability and attrition as measures of nonprofit performance. Annals of Public and Cooperative Economics, 62(4), 655-672. doi:https://doi.org/10.1111/j.1467-8292.1991.tb01372.x

Endang, K., \& Risal. (2017). The effect of investment decision financing decision dividend payment policy and company size. Journal of Administrative and Business Studies, 3(2), 105-113. doi:https://doi.org/10.20474/jabs-3.2.5

Hermanson, D. R., Smith, J. L., \& Stephens, N. M. (2012). How effective are organizations' internal controls? Insights into specific internal control elements. Current Issues in Auditing, 6(1), 31-50. doi:https://doi.org/10.2308/ciia-50146

Hernandez, R., Sampieri, Fernandez-Collado, C., \& Baptista-Lucio, M. (2014). Metodologia de la investigacion. New York, NY: McGraw-Hill.

Jaruga, A., Fijalkowska, J., \& Jaruga-Baranowska, M. (2007). The impact of IAS/IFRS on Polish accounting regulations and their practical implementation in Poland. Accounting in Europe, 4(1), 67-78. doi:https://doi.org/10.1080/ 17449480701308675

Kakanda, M. M., Salim, B., \& Chandren, S. A. (2018). Risk management committee characteristics and market performance: Empirical evidence from listed review hypotheses development. International Journal of Management and Applied Science, 3(6), 54-58.

Nordin, N., \& Hamid, M. A. (2013). Corporate risk management, firm characteristics, ownership structure, and governance attributes of banks: A case of Malaysia. Prosiding Perkem, 2(1), 655-660.

Ponce, H. G., Hlaciuc, E., Mateș, D., \& Măciucă, G. (2016). Empirical study of financial disclosure compliance with IFRS: Evidence from listed romanian companies. Journal of Accounting and Auditing: Research \& Practice, 3(7), 1-15. doi: https://doi.org/10.5171/2016.794159

Ramirez, R., \& Marlene, F. (2014). Impact of international financial information standards on the development of large family businesses in Peru (Unpublished master's thesis). University of San Martin de Porres, Lima, Peru.

Romero, N., \& Luna, A. (2015). Analisis de los cambios que ocasiona la implementacion de las normas internacionales de informacion financiera para PYMES-NIIF SME-en la estructura financiera de la agencia de Aduanas Ascointer SA (Unpublished master's thesis). University of Cartagena, Cartagena, Colombia.

Ruiz, M. (2018). Más del 50\% de mypes cierran antes de 3 años. Peru 21, 5(8), 80-100.

Santa Cruz, M. M. (2014). The internal control based on the COSO model. Journal of Research on Book Value, 1(1), 56-60. 
Sarea, A. M., \& Al Dalal, Z. A. (2015). The level of compliance with International Financial Reporting Standards (IFRS 7). World Journal of Entrepreneurship, Management and Sustainable Development, 11(3), 231-244. doi:https://doi.org/ 10.1108/wjemsd-02-2015-0009

Woods, M. (2012). Risk management in organizations: An integrated case study approach. London, UK: Routledge. 